\title{
Export Earnings Instability and Investment in Ghana, 1981 to 2011
}

\author{
Patricia Woedem Aidam, Kwabena Asomanin Anaman* \\ Institute of Statistical, Social and Economic Research, University of Ghana, Accra, Ghana \\ Email: patwoedem@yahoo.com, paidam@ug.edu.gh, ${ }^{*}$ kwabenaasomanin@hotmail.com, \\ kanaman@ug.edu.gh
}

Received 9 April 2014; revised 5 May 2014; accepted 15 May 2014

Copyright (C) 2014 by authors and Scientific Research Publishing Inc.

This work is licensed under the Creative Commons Attribution International License (CC BY). http://creativecommons.org/licenses/by/4.0/

c) (i) Open Access

\begin{abstract}
The study investigates the effect of the instability of export earnings on gross fixed capital formation (total investment) in Ghana over the period, 1981 to 2011, marked by continuous political stability. The analysis employs the autoregressive distributed lag (ARDL) method of cointegration to evaluate a set of factors, which affect investment as measured by the investment to gross domestic product (GDP) ratio. The results of the analysis confirm the expected negative relationship between export earnings instability and investment. Other factors that significantly influence investment in Ghana are real GDP growth, merchandise trade balance, real interest rate and gross domestic savings ratio. Based on the analysis, we recommend policy measures aimed at increasing the domestic savings ratio and export diversification given the re-emergence of reduced real values of Ghanaian export commodities in the world market after the high values of these commodities during the first decade of the 21 st century.
\end{abstract}

\section{Keywords}

Capital Formation, Export Instability, Ghana, Gross Fixed Capital Formation, Investment

\section{Introduction}

\subsection{Background}

Ghana was the first country in Sub-Saharan Africa to achieve political independence from European colonial powers in the 20th century. The first nine years of political independence saw moderate economic growth and increased level of socio-economic development anchored on the main pillars of free and compulsory basic education, free provision of health services and extensive infrastructural development financed through revenues

${ }^{*}$ Corresponding author. 
from the export of cocoa for which it was the leading producer for over half a century until 1978. The economy suffered a severe balance of payment problem largely due to the historically low levels of cocoa prices in 1965, which was a catalyst for military coup in February 1966. From 1966 to 1983, the country went through a period of political upheavals related to five successful military coups. The economy declined sharply during this period especially over the 1975 to 1983 period when there was a near collapse of the economy with gross fixed capital formation reaching a record low level of only 3.5\% of GDP in 1983. During this period there was a great deterioration in the export sector as a result of a number of factors including the over-valuation of the domestic currency, effects of the 1973-1980 world oil price shocks and the severe droughts of 1977 and 1983 now known to have been linked to the worst recorded level of the El Nino-Southern Oscillation weather phenomenon [1].

The economy recovered in 1984 and since 1984 the country has experienced 30 years of continuous positive annual economic growth from 1984 to 2013 with growth of 7.1\% in 2013. Annual growth of real GDP over this period ranged from $3.2 \%$ to $15.0 \%$. In 2011 , the country had the fastest growing economy in the world at $15 \%$ due partly to the export of oil and gas from newly discovered offshore fields. Real economic growth has averaged 7.6\% per year over the last ten years (2004 to 2013 period) and 8.6\% annual growth over the period, 2009 to 2013, making the country one of the top 15 economic performers in the world.

Despite recent impressive economic growth there are concerns of the long-term sustainability of the economy due to a number of factors. These include the persistence of very large national budget deficits during years of national elections since the re-emergence of civilian constitutional rule in 1992 during the Fourth Republic related to the two-party political polarisation [2]. Other long-term sustainability concerns related to economic sustainability include large merchandise trade deficits, growing levels of food imports, the recent depreciation of the national currency partly due to the significant slump in world commodity prices, intermittent electricity energy shortages and widening income inequality. The large merchandise trade imbalances and instability of export revenues are of particular concern as they directly affect ability to stimulate capital formation and economic growth.

\subsection{The Problem Statement}

Since the start of major exports from the country during the first decade of the 20th century, Ghana has traditionally produced three main commodities for the international markets. These are 1) cocoa, 2) gold and other minerals such as diamonds, bauxite and manganese and 3) timber and forestry products. Oil became the new significant export commodity for Ghana starting in 2011. In 2010, the Ghana Statistical Service declared that the country had achieved the status of a lower middle-income country after a GDP rebasing exercise This lowerincome status was achieved largely on the back of increased revenues from the country's traditional exports, increased foreign loans and grants including the cancellation of two-thirds of the country's external debts in 2006, increased foreign direct investments arising from the liberalisation of the economy, and relatively large amounts of remittances from over two million Ghanaians (about 10\% of its population) living outside the country.

Like many other developing countries, Ghana requires a substantial level of imports of capital and intermediate goods, oil and raw materials. The ability to import these goods however depends on the export earnings, the terms of trade, the extent of foreign borrowing and the exchange rate of the country. Historically, the decline in the growth of export values and the dependence on foreign exchange earnings from merchandise exports for a significant proportion of foreign exchange inflows had meant that the capacity to import capital goods was unreliable during the first four decades after independence from 1960 to 2000. Very low world prices of cocoa, Ghana's top foreign exchange earner, was one of the identified causes of both the 1966 and 1972 military coups. The domestic manufacturing sector is still highly import-dependent with most sectors depending on imported raw materials for a significant proportion of total requirement. Shortages in required raw materials, spare parts and capital goods were important determinants of excess capacity in the manufacturing sector.

Being a small open economy, Ghana depends on its export earnings to import capital goods, equipment and other inputs that it does not produce domestically. A greater proportion of her earnings from the exports sector are derived by its major traditional exports such as cocoa, timber and gold (Institute of Statistical, Social and Economic Research, University of Ghana) [3]. The dependence of Ghana on the earnings from her exports for the acquisition of foreign exchange implies that the rate of growth of the economy, to a large extent depends on the performance of the export sector. When export earnings are high, the country is likely to enjoy high investment and thus ensure a higher growth performance but a decline in export earnings would lead to a reduction in 
foreign exchange earnings. This in turn reduces the importation of capital and intermediate goods. As most tradable capital goods are not produced domestically, the unavailability of foreign exchange inevitably emerges as an important constraint on investment and growth.

Succeeding governments over the last 30 years of political stability, and since the new era of continuous economic growth starting in 1984, have recognised the fragility of the economy based on its excessive dependence on a few primary export commodities and have embarked on export-led growth through diversification of exports to achieve greater economic growth. In particular, the strategy of enhancing the growth of non-traditional agricultural exports has been pushed consistently since the 1990s. The concerted effort at increasing export supply is viewed as a means through which the country can generate a steadily rising level of foreign exchange for the importation of capital and consumer goods. It is against this backdrop that the study seeks to investigate the extent to which export earning instability influences the pattern and magnitude of investment in Ghana in the short-run as well as in the long-run periods.

Though various studies by a number of economists on investment and growth in Ghana exist, there is some gap in information dealing with the relationship between instability in export earnings and total aggregate investment in Ghana; the latter captures both locally generated investments and foreign direct capital inflows. This study therefore aims at filling this gap by showing the effect of export earnings instability on investment in Ghana especially during a relatively period of political stability where succeeding governments have largely continued most of the policies of their predecessors. We believe that this study is of relevance to the larger international audience given Ghana's recent record of political stability and democracy and rapid economic growth rates over the last decade (from 2004 to 2013) comparable to those of East Asian newly-industrialised countries, over the period from 1970 to 2000.

Utilising data mainly from a relatively long period of political stability in a developing country context (30 years), we believe that this paper contributes to the international literature and renews an interest in the Prebisch Singer Theory (PST) of declining real terms of commodities of developing countries developed independently in 1950 by economists, Raul Prebisch and Hans Singer [4] [5]. The PST states that over the long-term period, the international export prices of primary goods such as cocoa and coffee decline relative to those of manufactured goods such as cars and machines used for construction activities. In essence, countries with high dependence on unprocessed primary products such as coffee and cocoa lose out with worsening terms of trade since they would have to produce relatively larger quantities of exports to pay for the imports of essential raw materials and capital goods. PSH suggests that high world commodity prices generate only temporary windfall incomes, which disappear after a couple of years with commodity prices returning to relatively low levels.

The 2001 to 2010 period, the first decade of the 21st century, witnessed relatively high real prices of commodities produced by developing countries such as coffee, cocoa and gold after a volatile period of commodity price movements in international markets from 1970 to 2000. However, over the last three years (2011 to 2013), commodity prices have slumped considerably partly due to decreased demand from China and India and the general global economic slowdown. The issue of export instability has resurfaced as an important international trade issue with increasing merchandise trade deficits of many developing countries in Africa. It can be argued that the normal four-to-seven yearly cycles of booms and busts in international commodity prices were extended during the first decade of the 21st century by unusually high demand for raw materials from China and India; the normal patterns of international trade characterised by steadily declining long-run prices of commodities observed by Prebisch and Singer might have returned.

The main objective of this study is to analyse the relationship between export revenue instability and the relative level of gross fixed capital formation (investment). In order to fully specify a model that can address this objective, other factors that are likely to influence the relative level of investment are also analysed. The rest of this paper is organised as follows: Section 2 deals with a discussion of the literature with emphasis on the relationship between export revenue instability and total investment. The methodology employed for the study is detailed in Section 3 followed by a discussion of the results. The conclusions and policy recommendations follow.

\section{Literature Review}

\subsection{Introduction}

For many years, economists seemed to agree that export-earning instability damages the growth potential of less 
developed countries because of its effect on the income of producers and more generally on foreign exchange earnings. This in turn adversely affects the level and efficiency of investment ([6]-[9]). Since many developing counties use a substantial part of their earnings to produce or import capital goods, a considerable shortfall in foreign exchange receipts inhibits expansion of the export industry, which might also reflect in the level of total capital formation ([10] [11]). This suggests that there is a possible relationship between capital formation and export earnings, implying that output and economic growth can be significantly affected by instability from the earnings of exports. It is therefore important to study the links between export earnings and capital accumulation. The engagement in export trade depend not only on the existence of needs that cannot be satisfied by domestic production, but also on the possibility of exchanging domestically produced goods for foreign goods, mainly capital goods for investment purposes.

\subsection{Determinants of Export Instability}

It has been commonly held that exports of less developed countries fluctuate widely adding to the complexities of economic planning, which adversely affects the process of economic development. Specialization in primary and agricultural products as well as instability in their exports has long been considered as the major cause of export problems for least developed countries (LDCs). Domestic production is generally subject to greater shortrun variation than are expected often due to unpredictable natural forces. The export supply of these products is positively affected by increases in the country's total domestic export supply whereas the volume of export supply by the importing countries affects import demand. Primary products are known to have low price elasticity of supply and demand, which is said to cause even greater fluctuation of export proceeds in those countries relying heavily on them.

There are a number of measures for export instability from which to choose. As indicated by Glezakos [12] the term "export instability" as it is generally used refers to "unexpected" fluctuations in the export market. Such unexpected changes in the export sector necessitate sudden internal adjustments and complicated planning. In line with Massell [13] we analyse stability within the framework of a simple market model. Market fluctuations result from shifts in demand and supply with the relevant elasticities coming into play. The demand price elasticity of a country's exports is a function of the price elasticity of the world's demand and the country's share of the world's market for the commodity. As the country's share of the world's market declines, its demand price elasticity increases. Shifts in export supply in a given country are results of fluctuations in output or domestic demand for exported commodity. A number of authors have argued that geographical concentration of export sales results in greater export instability [13] [14]. If sales are geographically concentrated, fluctuations in demand conditions within a given importing country will have a relatively greater impact than if sales are more diversified.

\subsection{Relationship between Export Instability, Growth and Capital Formation}

There are several studies about the relationship between export earnings instability and capital formation (the major determinant of economic growth) and economic growth in general with diverse or conflicting opinions. Some economists argue that there is a significant negative effect of export earnings instability on investment and economic growth while others are of the opinion that the relationship is a positive one. Others found no relationship between export instability and investment and economic growth. The studies that argue that there is a negative relationship between exports earnings instability and economic growth attribute it to the uncertainty created in long term planning and shortages of critical imported inputs ([15]). Authors who found a positive relationship between the two variables opine that if we assume risk-averse behaviour, uncertainty about export earnings can lead to a reduction in consumption and in turn, an increase in saving and investment and thus economic growth [16]).

A study to assess the impact of export earnings instability of primary commodity and the level of commodity dependence on economic growth in Sub Saharan Africa using fixed effects panel data estimator found that instability in exports was negatively related to economic growth [15]. The link between export earnings instability and capital formation through a model of the investment behaviour where both effects of export earnings instability and financial constraints on capital formation has been undertaken [17]. A country-specific approach for 12 developing countries during the period 1963-1983 was used. He found out that export earnings instability was seen to affect investment in seven of the countries and finally concluded that the overall effect of export 
earnings instability on investment could be positive [17]. A positive relation between export instability and investment has been established using time-series data for eight countries [18]. A similar study to assess the effects of volatility of exports in the Philippines and Thailand using the GARCH model concluded that the shock to export volatility was permanent [16].

A study about export earnings fluctuation and capital formation in Nigeria also discovered that export earnings fluctuations adversely impinged on investment in the short-run period. Love established that export instability caused income instability based on a time-series study of 20 developing countries [19]. A study of 34 SubSaharan African countries during the 1960 to 1986 period using the production function framework found that export instability had a negative effect on economic growth irrespective of how export instability was measured [20]. Other studies that established some significant linkage between export instability and investment or income include ([21]-[23]).

\section{Methodology}

\subsection{Introduction}

The study adopts the standard normalization approach combined with a moving average method. The merits of this method are that it distinguishes between rise and fall, temporary and permanent, and stochastic and predictable changes of export earnings. This approach has been used to estimate export earnings fluctuation for Nigeria [19]. The export earnings instability index $\left(F T_{t}\right)$ is obtained by applying the formula below:

$$
F T_{t}=\frac{X_{t}-X 4_{j}}{\sigma 4_{j}}
$$

But, $X 4_{j}=\frac{1}{4} \sum_{j-t-3}^{1} X_{j}$; where: $X_{t}=$ export earnings; $\sigma 4_{j}=$ standard deviation of the export earnings of a four-year period; $X 4_{j}=$ moving average over the same four-year period.

Generally, it is assumed that expected output is a function of current and past output levels, However, this study uses the general distributed lag method in which expected output is related to its past values ([24]), so that

$$
Q_{t}^{*}=a_{0}+\sum_{t=1}^{n} b_{j} \log Q_{t-1}
$$

where, $Q^{*}=$ expected output; $Q=$ actual output proxied by GDP; $a_{0}$ and $b_{j}$ are coefficients.

\subsection{Model Specification}

The specification draws from the works of ([17] and [19], [25]). This is stated below in Equation (3).

$$
\text { INVEST }_{t}=A_{0}+A_{1} \mathrm{FT}_{t}+A_{2} \text { EGROWTH }_{t}+A_{3} \mathrm{RNT}_{t}+A_{4} \mathrm{TBAL}_{t}+A_{5} \mathrm{SRATIO}_{t}+U_{t}
$$

where INVEST $T_{t}$ is the ratio of total fixed capital formation divided by GDP in year $t$;

$\mathrm{FT}_{t}$ is the measure of export revenue instability (defined earlier) for year $t$;

EGROWTH $_{t}$ is the annual growth of the real gross domestic product in year $t$;

$\mathrm{TBAL}_{t}$ is the merchandise trade balance (deficit) in year $t$; the difference between merchandise exports and merchandise imports which is always negative and expressed in the model as a positive number.

RNT is the real interest rate in year $t$;

$\mathrm{SRATIO}_{t}$ is the domestic savings ratio for year $t$;

$A_{i}(i=0,1,2,3,4$ and 5$)$ are the parameters to be estimated; and

$U_{t}$ is the error term of the model assumed to have a mean of zero and constant variance.

A long-run growth function, as shown in Equation (4), if it is a valid cointegration function, will also have an equivalent short-run error correction model (ECM). The short run ECM is shown in Equation (4) as follows:

$$
\Delta \text { INVEST }_{t}=B_{0}+B_{1} \Delta \mathrm{FT}_{t}+B_{2} \Delta \mathrm{EGROWTH}_{t}+B_{3} \Delta \mathrm{RNT}_{t}+B_{4} \Delta \mathrm{TBAL}_{t}+B_{5} \Delta \mathrm{SRATIO}_{t}+B_{6} U_{t-1}+W_{t}
$$

where $U_{t-1}$ is the lagged error term from the co-integration equation depicted in Equation (3), $W_{t}$ is a normal random error term, $\Delta$ is the first difference operator and $B_{i}(i=0,1,2,3,4,5,6)$ are the parameters to be estimated.

Equations (3) and (4) were estimated using the Autoregressive Distributed Lag (ARDL) co-integration method given the time-series nature of the data and the need to avoid spurious regression analysis. The two steps 
involved with the ARDL method are as follows: First, the analyst establishes a long-run relationship among the variables in the model by a bounds test and its associated unrestricted error correction model. The second step deals with the derivation of the long-run relationship from the unrestricted error correction model once a longrun relationship among the variables has been confirmed [26].

\subsection{Data and Data Sources}

Data used were from secondary sources and were sourced from the World Bank database for Ghana covering the period, 1980 to 2011. All variables are measured in domestic currency units and real values established using appropriate deflators.

\section{Results}

The results of the three standard tests for unit roots in the variables of the model are reported in Table 1. Using the Augmented Dickey-Fuller (ADF) test, the unit root test results showed that the FT and SRATIO were stationary. However, the other three variables in the model-INVEST, EGROWTH, RNT and TBAL-were nonstationary. Using the Phillips-Peron (PP) and Kwiatkowski, Phillips, Schmidt and Shin (KPSS) tests, it was realised that some variables were stationary and others were not at $5 \%$ significant level. For the first difference, all the variables were stationary based on the PP and KPSS test that is they were integrated of the order I (1).

Given a mixture of stationary and non-stationary variables in the model as established from the three standard unit root tests, the ARDL co-integration procedure is the ideal method for analysis. The results of the estimated optimal ARDL model based on the Schwarz-Bayesian criterion are reported in Table 2. The overall power of the ARDL model was good with an adjusted $\mathrm{R}^{2}$ of $94.5 \%$ meaning that only about $5.5 \%$ of the variation in the dependent variable could not be explained by the four independent variables. The model was correctly specified as indicated by the lack of significance based on the Ramsey Reset Test. There was no significant heteroscedasticity based on the lack of significance of the Langrange Mulitiplier (LM) test. Similarly, the LM test for serial correlation revealed the absence of this problem. The diagnostic test for normality of the error term showed that the error term was normally distributed and hence the standard Student $t$ values were valid in projecting the sample results to the unknown population.

With the absence of any significant econometric problem and the high power of the model, long run parameter estimates were derived. These long run parameter estimates are reported in Table 3 and they showed that

Table 1. The results of unit root test.

\begin{tabular}{|c|c|c|c|c|c|c|c|c|c|c|c|c|}
\hline \multirow{3}{*}{ Variables } & \multicolumn{4}{|c|}{ ADF test statistic } & \multicolumn{4}{|c|}{ Philip Perron (PP) test statistic } & \multicolumn{4}{|c|}{ KPSS test statistic } \\
\hline & \multicolumn{2}{|c|}{ Level } & \multicolumn{2}{|c|}{ 1st difference } & \multicolumn{2}{|c|}{ Level } & \multicolumn{2}{|c|}{ 1st difference } & \multicolumn{2}{|c|}{ Level } & \multicolumn{2}{|c|}{ 1st difference } \\
\hline & $\begin{array}{l}\text { With } \\
\text { intercept } \\
\text { and no } \\
\text { trend }\end{array}$ & $\begin{array}{l}\text { With } \\
\text { intercept } \\
\text { and trend }\end{array}$ & $\begin{array}{l}\text { With } \\
\text { intercept } \\
\text { and no } \\
\text { trend }\end{array}$ & $\begin{array}{c}\text { With } \\
\text { intercept } \\
\text { and trend }\end{array}$ & $\begin{array}{l}\text { With } \\
\text { intercept } \\
\text { and no } \\
\text { trend }\end{array}$ & $\begin{array}{c}\text { With } \\
\text { intercept } \\
\text { and trend }\end{array}$ & $\begin{array}{l}\text { With } \\
\text { intercept } \\
\text { and no } \\
\text { trend }\end{array}$ & $\begin{array}{c}\text { With } \\
\text { intercept } \\
\text { and trend }\end{array}$ & $\begin{array}{l}\text { With } \\
\text { intercept } \\
\text { and no } \\
\text { trend }\end{array}$ & $\begin{array}{c}\text { With } \\
\text { intercept } \\
\text { and trend }\end{array}$ & $\begin{array}{l}\text { With } \\
\text { intercept } \\
\text { and no } \\
\text { trend }\end{array}$ & $\begin{array}{l}\text { With } \\
\text { intercept } \\
\text { and trend }\end{array}$ \\
\hline INVEST & -1.064 & -3.293 & $-7.941^{*}$ & $-7.927^{*}$ & -0.536 & $-4.009^{*}$ & $-10.145^{*}$ & $-9.965^{*}$ & 0.391 & $0.139^{*}$ & $0.162^{*}$ & $0.147^{*}$ \\
\hline FT & $-3.439^{*}$ & $-3.781^{*}$ & $-10.282^{*}$ & $-11.578^{*}$ & $-4.252^{*}$ & $-4.771^{*}$ & $-14.273^{*}$ & $-15.498^{*}$ & $0.350^{*}$ & $0.157^{*}$ & $0.212^{*}$ & $0.212^{*}$ \\
\hline NGROWTH & -2.296 & -3.311 & $-5.272^{*}$ & $-5.192^{*}$ & -1.291 & -2.325 & $-5.907^{*}$ & $-5.755^{*}$ & 0.459 & $0.140^{*}$ & $0.258^{*}$ & $0.174^{*}$ \\
\hline RNT & -2.368 & -3.050 & $-5.823^{*}$ & $-5.724^{*}$ & -2.818 & $-4.412^{*}$ & $-13.619^{*}$ & $-17.807^{*}$ & 0.383 & $0.155^{*}$ & $0.228^{*}$ & $0.213^{*}$ \\
\hline NTBAL & -1.871 & -2.258 & $-5.970^{*}$ & $-6.309^{*}$ & -2.012 & -3.103 & $-9.021^{*}$ & $-11.934^{*}$ & $0.352^{*}$ & $0.157^{*}$ & $0.276^{*}$ & $0.189^{*}$ \\
\hline SRATIO & $-3.676^{*}$ & $-3.656^{*}$ & $-5.208^{*}$ & $-5.058^{*}$ & $-3.878^{*}$ & $-3.851^{*}$ & $-9.417^{*}$ & $-9.032^{*}$ & $0.220^{*}$ & $0.147^{*}$ & $0.197^{*}$ & $0.192^{*}$ \\
\hline
\end{tabular}

*Significant at 5\% level, critical values at 5\% level. ADF: critical value at level intercept no trend $=-2.963$. ADF: critical value at level intercept and trend $=-3.567$. ADF: critical value at first difference with intercept and no trend $=-2.9665$. ADF: critical value at first difference with intercept and trend $=-3.5731$. PP: critical value at level intercept no trend $=-2.9605$. PP: critical value at level intercept and trend $=-3.5375$. PP: critical value at first differencing with intercept and no trend $=-2.9272$. PP: critical value at first differencing with intercept and trend $=-3.5387$. KPSS: critical value at level intercept and no trend $=0.38426$. KPSS: critical value at level intercept and trend $=0.24467$. KPSS: critical value at first differencing with intercept and no trend $=0.38426$. KPSS: critical value at first differencing with intercept and trend $=0.24467$. 
Table 2. Results of estimated optimal ARDL model of investment in Ghana based on data from 1981 to 2011. Dependent variable is INVEST $_{t}$.

\begin{tabular}{cccc}
\hline Explanatory variable & Parameter estimate & T-statistic & P value \\
\hline INTERCEPT & 8.083 & 3.446 & $0.002^{*}$ \\
INVEST $_{t-1}$ & 0.227 & 2.471 & $0.021^{*}$ \\
FT $_{t}$ & -5.142 & -3.878 & $0.001^{*}$ \\
RNT & -16.042 & -3.589 & $0.002^{*}$ \\
RNT $_{t-1}$ & 12.358 & -3.015 & $0.006^{*}$ \\
EGROWTH $_{t}$ & 0.988 & 6.269 & $0.000^{*}$ \\
TBAL $_{t}$ & 0.789 & 7.237 & $0.000^{*}$ \\
SRATIO $_{t}$ & 0.425 & 4.096 & $0.000^{*}$ \\
\hline
\end{tabular}

$\mathrm{R}^{2}$ : $0.958^{*}$. Adjusted $\mathrm{R}^{2}: 0.945^{*}$. Probability level of significance of model specification based on the Ramsey Reset test of correct model specification: 0.609. Probability level of significance level for autocorrelation based on the Langrange Multiplier (LM) test: 0.957. Probability level of significance for heteroscedasticity based on the LM heteroscedasticity test: 0.315 . Probability level of significance for normality of the error term Based on the Jarque-Bera test: 0.845 . Note: ${ }^{*}$ Denotes that parameter is statistically different from zero at $5 \%$ level.

Table 3. Results of estimated long-run relationship derived from the optimal ARDL model of investment in Ghana based on data from 1981 to 2011. Dependent variable is INVEST $_{t}$.

\begin{tabular}{cccc}
\hline Explanatory variable & Parameter estimate & T-statistic & P value \\
\hline INTERCEPT & 10.452 & 3.737 & $0.001^{*}$ \\
EGROWTH $_{t}$ & -6.649 & -3.790 & $0.001^{*}$ \\
RNT $_{t}$ & 1.278 & 5.589 & $0.000^{*}$ \\
TBAL $_{t}$ & -4.764 & -0.703 & 0.489 \\
SRATIO $_{t}$ & 1.020 & 8.003 & $0.000^{*}$ \\
\hline
\end{tabular}

almost all the independent variables-FT, EGROWTH, TBAL and SRATIO significantly influenced the level of INVEST but RNT did not influence investment in the long run. As expected, instability in export revenues (FT) and real interest rate had a negative impact on investment. Increased economic growth and increased domestic savings ratios both positively affected the level of investment as expected. Increasing merchandise trade deficit also positively influenced the level of investment, suggesting as earlier pointed out, the increasing need for the importation of capital inputs to increase the level of investment in Ghana.

The parsimonious short-run error correction model linked to the long-run function was also estimated and the results are reported in Table 4. The results show that all the six independent variables significantly influenced the dependent variable. Short-run changes in investment were positively influenced by short run changes in economic growth, merchandise trade deficit and domestic savings ratio. However, short-run changes in export revenue instability and real interest rate negatively affected short-run changes in investment. The parameter estimate of the error correction was -0.773 (refer to Table 4). This meant that the long-run equilibrium would be restored after about 1.3 years or one year three and half months of disequilibrium caused by shocks. The statistically significant error correction term suggested that the independent variables in the long-run model Grangercause or preceded investment and hence justified the use of the single-equation model for the study. It is clear from the study that in both the short-run and long-run periods, export revenue instability affected investment in the negative. 
Table 4. Results of estimated short-run parsimonious error correction model derived from the long-run model of investment in Ghana based on data from 1981 to 2011. Dependent Variable is $\Delta$ INVEST $_{t}$.

\begin{tabular}{cccc}
\hline Explanatory variable & Parameter estimate & T-statistic & P value \\
\hline $\mathrm{FT}_{t}$ & -5.142 & -3.878 & $0.001^{*}$ \\
$\Delta$ EGROWTH $_{t}$ & 0.988 & 6.269 & $0.000^{*}$ \\
$\Delta \mathrm{RNT}_{t}$ & -16.042 & -3.589 & $0.001^{*}$ \\
$\Delta$ TBAL $_{t}$ & 0.789 & 7.237 & $0.000^{*}$ \\
$\Delta$ SRATIO $_{t}$ & 0.425 & 4.096 & $0.000^{*}$ \\
$\mathrm{U}_{t-1}$ & -0.773 & -8.429 & $0.000^{*}$ \\
\hline
\end{tabular}

Note: ${ }^{*}$ Denotes that parameter is statistically different from zero at $5 \%$ level.

\section{Conclusions and Policy Recommendations}

We investigated the determinants of total investment in Ghana as measured by the level of gross fixed capital formation as proportion of GDP over the 30-year period, 1981 to 2011, which was marked by political stability. In particular, we emphasised the effect of the instability in export earnings on the level of investment. As expected, our results confirmed negative relationship between total investment and export earnings instability both in the short-run and long-run periods. We also established that real GDP growth, merchandise trade balance deficit and gross domestic savings ratio positively influenced the level of total investment both in the short-run and long-run periods. However real interest rate had a significant effect on total investment only in the short-run period.

Our results corroborated those of [19] in Nigeria and [11] that export earnings instability affected the rate of capital formation and investment. Ghana's rapid economic growth rate over the last decade has been partly due to the high rate of domestic and foreign direct investment inflows into the economy. In particular, the economic growth has been driven by the construction industry ([27]), which is traditionally heavily dependent on imports. With export revenues instability affecting the rate of investment, this information would suggest that the government should continue its current broad-based approach to export diversification, which has yielded some tangible results in the relatively rapid growth of non-traditional exports over the last two decades. Further, Ghanaian policymakers and advisors should expand the diversification strategy into manufacturing processes that the country has clear current comparative advantages such as food processing, garments, oil-based products and processing of minerals. Emphasis needs to be placed on the promotion of manufactured exports. In this regard, the setting up of more Export Processing Zones should be given more impetus.

An export earnings stabilization scheme is likely to stimulate capital formation by minimizing the debilitating effect of instability in export earnings in both the short-run and long-run. This could be done by the expansion of existing export stabilisation schemes for gold, cocoa and other crops as a means of also helping to control the depreciation of the Ghanaian currency, the Ghana Cedi, which has suffered significant depreciation over the last two years partly due to falls in the prices of cocoa and other commodities in the international markets. Cocoa and other commodity stabilisation funds should be given major priority by the government with emphasis on moderate increases in the local prices of export crops such that bigger stabilisation funds can allow for increases in local prices during times of lower international prices.

Finally, although the government is making some effort such as the introduction and implementation of export development and investment fund, it still has a lot to do in terms of helping exporters to acquire financial assistance from the banks. It is our considered opinion that these policy measures should ensure an adequate and sustainable formation of capital for a sustainable development in the economy. Financial development should be enhanced to reduce financial repression, which discourages investment thereby affecting export growth. Thus, there is a need to focus on creating conditions for raising domestic savings rates and to reduce capital flight to such savings. 


\section{Acknowledgements}

We thank the Office of Research, Innovation and Development, University of Ghana, Legon, Accra, Ghana for sponsoring the study.

\section{References}

[1] Anaman, K.A. (2006) Factors That Enabled Successful Economic Reform and Recovery in Ghana from 1983 to 2006. IEA Monograph Number 11, Institute of Economic Affairs, Accra, 40 p.

[2] Anaman, K.A. and Agyei-Sasu, F. (2012) Impact of Democratic Political Transition on the Performance of Business Firms in Ghana. Economic Papers: A Journal of Applied Economics and Policy, 31, 391-400.

[3] Institute of Statistical Social and Economic Research (ISSER) (2013) The State of the Ghanaian Economy in 2012. ISSER, University of Ghana, Accra.

[4] Prebisch, R. (1962) The Economic Development of Latin America and Its Principal Problems. Economic Bulletin for Latin America, 7, 1-22.

[5] Singer, H.W. (1950) U.S. Foreign Investment in Underdeveloped Areas: The Distribution of Gains between Investing and Borrowing Countries. American Economic Review, 40, 473-485.

[6] Moran, C. (1983) Export Fluctuations and Economic Growth. Journal of Development Economics, 12, 195-218. http://dx.doi.org/10.1016/0304-3878(83)90039-1

[7] Fosu, A.K. (1992) Effect of Export Instability on Economic Growth in Africa. The Journal of Developing Areas, 26, 323-332.

[8] Borumand, S., Taghi, M., Bigdeli, Z. and Rezaei, E. (2009) Exports Instability, Capital Accumulation and Economic Growth: The Case of Iran. Quarterly Journal of Quantitative Economics, 6, 21-36.

[9] Chimoba, O.P. (2010) The Estimation of Long Run Relationship between Economic Growth, Investment and Export in Nigeria. International Journal of Business and Management, 5, 215-222.

[10] Kenen, P.B. and Voivodas, C. (1973) Export Instability and Economic Growth. Kylos, 25, 791-801. http://dx.doi.org/10.1111/j.1467-6435.1972.tb01082.x

[11] Aiello, F. (1999) Financial Stabilization Systems, Economic Growth of Developing Countries and EU’s STABEX. University of Calabria, Italy.

[12] Glezakos, C. (1984) Export Instability and Economic Growth: Reply. Economic Development and Cultural Change, 32, 229-236. http://dx.doi.org/10.1086/451409

[13] Massell, B.F. (1970) Export Instability and Economic Structure. American Economic Review, 60, 618-630.

[14] Coppock, J. (1960) International Economic Instability. McGraw Hill, New York.

[15] Ocran, M.K. and Biekpe, N. (2008) Primary Commodity Export and Economic Growth in Sub-Saharan Africa: Evidence from Panel Data Analysis. South African Journal of Economic and Management Sciences, 11, 465-474.

[16] Sinha, D. (2007) Effects of the Volatility of Exports in the Philippines and Thailand. The IUP Journal of Financial Economics, 5, 78-83.

[17] Stordel, H. (1990) Export Income Risk and Determinants of Capital Formation in Developing Countries. Weltwirtschaftsliche Archiv, 126, 346-368.

[18] Sinha, D. (1999) Export Instability, Investment and Economic Growth in Asian Countries. Economic Growth Centre, Yale University and Macquarie University, Sydney.

[19] Akpokodje, G. (2000) The Effect of Export Earning Fluctuations on Capital Formation in Nigeria. Nigeria Institute of Social and Economic Research, Ibadan.

[20] Gyimah-Brempong, K. (1991) Export Instability and Economic Growth in Sub-Saharan Africa. Economic Development and Cultural Change, 39, 815-828. http://dx.doi.org/10.1086/451909

[21] Khan, A.H. and Saqib, N. (1993) Export Expansion and Economic Growth: Further Empirical Evidence. Journal of Development Economics, 18, 1-12.

[22] Krishna, K., Ozyildirim, A. and Swanson, N. (1998) Trade, Investment and Growth: Nexus, Analysis and Prognosis. NBER Working Paper No. 6861.

[23] Levine, R. and Renelt, D. (1992) A Sensitivity Analysis of Cross-Country Growth Regressions. American Economic Review, 82, 942-963.

[24] Bischoff, C.W. (1969) Hypothesis Testing and the Demand for Capital Goods. The Review of Economics and Statistics, 51, 354-368. http://dx.doi.org/10.2307/1926570 
[25] Blejer, M.I. and Khan, M.S. (1984) Government Policy and Private Investment in Developing Countries. IMF Staff Papers, 31, 379-403. http://dx.doi.org/10.2307/3866797

[26] Pesaran, H.M., Shin, Y. and Smith, R.J. (2001) Bounds Testing Approaches to the Analysis of Long-Run Relationships. Working Paper No. 9907, University of Cambridge, Cambridge.

[27] Anaman, K.A. and Osei-Amponsah, C. (2007) Analysis of the Causality Links between the Growth of the Construction Industry and the Growth of the Macro-Economy in Ghana. Construction Management and Economics, 25, 951-961. http://dx.doi.org/10.1080/01446190701411208 